\title{
Advances in Mexican Bryology
}

\author{
Claudio Delgadillo $\mathrm{M}$. \\ Instituto de Biología, UNAM, Apartado Postal 70-233, 04510 México, D.F.
}

\begin{abstract}
After some 150 years of research there are more than 575 publications on Mexican bryophytes. Most of these appeared in the last two decades; it is suggested that research toward the preparation of the Manual of Mexican mosses increased the rate publication for that period of time.
\end{abstract}

Ever since the publication of my bibliographic compilations (Delgadillo 1969, 1975), I have been concerned with progress in Mexican Bryology. Recent years have seen the publication of numerous contributions, but there has been no comment as to their significance; time is ripe to evaluate these data and the work accumulated in more than 150 years of research on Mexican bryophytes.

This contribution attempts to provide a preliminary analysis of the literature and highlight certain developments that have occurred through the years. For this purpose, my bibliographic records have been updated to include information up to June 15, 1989. The records on which the following discussion is based were selected because they were directly related to events or plants from Mexico or listed Mexican specimens on which further research had been conducted. A bibliographic database was prepared to facilitate storage and retrieval of data.

Interest in Mexican bryophytes goes back to 1552 when De la Cruz reported the use of certain mosses in the treatment of several human illnesses. Althogh Hernández, the physician of the Spanish king Philip II, made reference to a species of
Plagiochasma in 1651, it was not until mid nineteen century when formal studies on Mexican bryophytes were begun. The first such study, according to my records, is that of Schlechtendal \& Chamisso (1831).

The second half of the nineteen century brought important advances in the floristic knowledge of Mexican bryophytes. Works by Bescherelle (1872), Gottsche (1863) and Müller (1848-1851) were perhaps the most important floristic landmarks of the century; the first two listed the mosses and liverworts known from Mexico. No other fields of research were investigated except for the morphological studies necessary for the description of taxa. This trend is still part of present-day research on the area.

In the early 1900's little bryological work was done on Mexico. Many of the bibliographic references of the first thirty years were contributed by Cardot, Evans and Bartram and almost without exception they listed or described taxa. In the following twenty years Bartram and others maintained their interest in the bryoflora of Mexico; Bartram published several articles on various parts including Coahuila and Sonora, the alpine areas and the 
TABLE 1. Number of works on Mexican bryophytes published during this century.

\begin{tabular}{lcrrr}
\hline DECADE & Bryophyta & Hepaticae & Mosses & TOTAL \\
\hline $1901-10$ & 2 & 1 & 9 & 12 \\
$1911-20$ & 1 & 7 & 11 & 19 \\
$1921-30$ & 0 & 3 & 15 & 18 \\
$1931-40$ & 3 & 6 & 7 & 16 \\
$1941-50$ & 3 & 13 & 32 & 48 \\
$1951-60$ & 5 & 13 & 28 & 46 \\
$1961-70$ & 5 & 13 & 44 & 73 \\
$1971-80$ & 4 & 34 & 114 & 131 \\
$1981-89$ & 9 & 114 & 405 & 188 \\
TOTAL & 32 & & & 551 \\
\end{tabular}

TABLE 2. Number of works on Mexican bryophytes published on or before 1972 and on or after 1973.

\begin{tabular}{lrrr}
\hline TAXA & -1972 & $1973-$ & TOTAL \\
\hline Bryophyta & 23 & 13 & 36 \\
Hepaticae & 73 & 46 & 119 \\
Mosses & 177 & 243 & 420 \\
TOTAL & 273 & 302 & 575
\end{tabular}

and floristic novelties linking Mexico to other parts of the world.

A. J. Sharp was among the first to initiate bryogeographical inquiries on Mexican mosses. Herzog (1926) had already made general statements concerning the distribution of mosses in the Americas and elsewhere, but Sharp detected floristic relationships between Mexico and the southeastern United States and Asia. These were described in a series of papers dating back to 1938 .

By the mid 1950 's, Crum and several others were making important contributions to Mexican bryology in the form of floristic and taxonomic reports. Crum's papers were soon followed by publications by Robinson, Pursell and Reese; a younger generation of bryologists including Vitt, Zander and Delgadillo continued the floristic, taxonomic and phytogeographic trends established by their predecessors. In the early 1970 's sufficient numbers of bryologists had become involved in Mexican moss research that the launching of a major work, the Manual of Mexican mosses, seemed a potentially successful venture. Sharp made the announcement in 1972.

The number of publications per year had been comparatively low before the 1960 's (cf. Table 1), but the increasing number of individuals working with Mexican bryophytes resulted in a larger number of papers published during this 
TABLE 3. Interesting records from studies on Mexican brophytes.

\begin{tabular}{ll}
\hline RECORD & Date or Reference \\
\hline Oldest reference & De la Cruz (1552) \\
oldest reference to liverworts & Hernández (1651) \\
lst reference by Mexican author & Ruiz (1942) \\
lst fossil, Lejeunea palaeomexicana & Grolle (1984) \\
Mexican research group established & 1973 (1980 \\
lst hybrid moss described & Delgadillo (1989)
\end{tabular}

TABLE 4 . Authors who have published ten or more contributions related to Mexican bryophytes.

\begin{tabular}{ll|ll}
\hline AUTHOR & \multicolumn{2}{l}{ No. contributions } & AUTHOR \\
\hline BARTRAM & 16 & 16 & FRAHM \\
BUCK & 13 & 13 & PURSELL \\
CARDENAS & 12 & 12 & REESE \\
CARDOT & 12 & 14 & ROBINSON \\
CLARK & 13 & 40 & SHARP \\
CRUM & 44 & 15 & VITT \\
DELGADILLO & 44 & 31 & ZANDER \\
\hline
\end{tabular}

decade. It is my belief that Sharp's announcement, a wider distribution of specimens from his laboratory and, in general, a broader concern for Mexican mosses were the factors responsible for the growing numbers of publications which have appeared since 1972 .

It seems that about thirty bryologists from around the world (Sharp 1977) have been engaged in research towards the publication of the Manual of Mexican mosses. New records, nomenclatural changes and taxonomic rearrangements have resulted from these inquiries; the contributions by Bowers, Buck, Frahm and Zander are particularly significant in this respect. However, for an overall analysis, it is necessary to look at the figures of papers produced before and after 1973 .

For the period between 1831-1972, the number of bryological titles for Mexico was 273, 177 of which dealt with mosses alone. By comparison, 302 were published during the last sixteen years; 243 of them were devoted to mosses (Table 2). A further look at these figures indicate that while work on mosses has steadily increased, the rate of growth in the number of publications for liverworts has been substantially lower (cf. Table 1). While this is certainly due to the lower number of hepaticologists, it is also due to encouragement of the study of mosses by the Manual project and the independent work of other bryologists. 
figures of papers produced before and after 1973.

For the period between 1831-1972, the number of bryological titles for Mexico was 273, 177 of which dealt with mosses alone. By comparison, 302 were published during the last sixteen years; 243 of them were devoted to mosses (Table 2). A further look at these figures indicate that while work on mosses has steadily increased, the rate of growth in the number of publications for liverworts has been substantially lower (cf. Table 1). While this is certainly due to the lower number of hepaticologists, it is also due to encouragement of the study of mosses by the Manual project and the independent work of other bryologists.

In addition to the Manual project, other features characterized the bryological work of the last two decades. A bryological group was formally established at the National University of Mexico in late 1973; this encouraged the development of bryological herbaria at MEXU and XAL and the growth of a small collection at ENCB; it also promoted floristic and phytogeographical studies and offered bryological training to other individuals such as Cardenas, De Luna and Equihua who are now beginning to make important contributions. While the emphasis on taxonomy, floristics and phytogegraphy persisted during the last two decades, studies in other fields began to appear in Mexico and elsewhere. There are publications dealing at least in part with the following subjects in which Mexican material has been studied: Phylogeny, phytochemistry, dispersal, and ontogeny. Other data of interest are given in Tables 3 and 4.

The preceding historical review indicates that progress in Mexican bryology has been substantial in the last two decades. As we look into the future of this discipline as it applies to Mexico, we cannot ignore the fact that the records of more than 150 years have but uncovered the vastness of the job ahead. On the eve of the publication of such important works as the Manual of Mexican mosses and of an equivalent catalogue for the leafy liverworts, bryophytes are still undercollected in many areas and even entire states such as Aguascalientes, Colima, Guanajuato, Quertaro and Tabasco are seldomly cited in the bryological records. Despite present knowledge, we require major collecting programs for Anthocerotopsida and the Hepaticae in the entire country.

The historical emphasis on taxonomy and floristics, and more recently, on phytogeography, must be strengthened and tied up with other fields of research. In addition, there is ample opportunity for those interested in pragmatic research (pollution, antibiotic activity and antitumor agents) which is urgently required.

\section{Literature Cited}

Bescherelle, E. 1872. Prodromus Bryologiae Mexicanae ou énumaration des mousses du Mexique avec description des especes nouvelles. M'em. Soc. Nat. Sci. Natur. Cherbourg 16: 144-256.

Crum, H. A. 1951. The Appalachian-Ozarkian element in the moss flora of Mexico with a check-list of all known Mexican mosses. Ph. D. Dissertation. Univ. Michigan. Ann Arbor. De la Cruz, M. 1552. Libellus de medicinalibus indorum herbis. Latin translation by Juan Badiano. IMSS, 1964. Mexico.

Delgadillo M., C. 1969. Literatura para las briofitas de México. Bol.Soc. Bot. Méx. 30: 127-135.

Delgadillo M., C. 1975. Literatura adicional para las briofitas de México. Bol. Soc. Bot. Méx. 35: 7-12.

Delgadillo M., C. 1989. Astomiopsis x altivallis (Musci: Dicranaceae), a putative interspecific hybrid in Mexico. Bryologist 92:225-227.

Fulford, M. 1946. The genus Bazzania in Central and South America. Chronica Bot. Co. Walltham, Mass.

Fulford,M. 1959. Studies on Americanhepaticae. 7. A supplement to "The genus Bazzania in Central and South America". Part I. Introduction and the subgenus Bidentatae. Bull. Torrey Bot. Club86:308-341.

Fulford, M. 1963-1976. Manual of the leafy hepaticae of Latin America. Part I-IV. Mem. New York Bot. Gard. 11: 1-535.

Gottsche, C. M. 1863. Die mexicanske Levermosser. Efter Prof. 